\title{
Bangladeshi Wild Date Palm Fruits (Phoenix sylvestris): Promising Source of Anti-cancer Agents for Hepatocellular Carcinoma Treatment
}

\author{
Farhana Shikder Lamia (Doushney Fatima Mukti** \\ Department of Genetic Engineering and Biotechnology, East West University, Aftab Nagar, Dhaka-1212, Bangladesh.
}

Article Information
Received: 09 February 2021
Revised version received: 10 March 2021
Accepted: 15 March 2021
Published: 30 march 2021
Cite this article as:
F.S. Lamia and R.F. Mukti (2021) Int. J. Appl. Sci.
Biotechnol. Vol 9(1): $32-37$.
DOI: $10.3126 /$ ijasbt.v9i1.36110

*Corresponding author

Roushney Fatima Mukti,

Department of Genetic Engineering and Biotechnology,

East West University, Aftab Nagar, Dhaka-1212,

Bangladesh.

Email: roushney@ewubd.edu

Peer reviewed under authority of IJASBT

(C) 2021 International Journal of Applied Sciences and

Biotechnology

\section{OPENDACCESS}

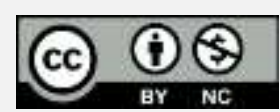

This is an open access article $\&$ it is licensed under a Creative Commons Attribution Non-Commercial 4.0 International (https://creativecommons.org/licenses/by-nc/4.0/)

Keywords: Anticancer agent; hepatocellular carcinoma; Phoenix sylvestris.

\begin{abstract}
Many natural products such as fruits and vegetables are promising amends as safe, effective and affordable approaches to control cancer development and progression, since they are inexpensive and available without any hazards. For instance, the aqueous extract of Ajwa dates (Phoenix dactilyfera) has been found to improve liver function through the restoration of anti-oxidant enzymes, liver enzymes, and cytokines balance and gene expression to normal levels. As the treatment and prognosis of Hepatocellular carcinoma, one of the leading causes of cancer associated deaths globally, has been found to be better if the liver function of the patient can be preserved, Ajwa date extract has been used together with the conventional therapeutics for the treatment of this disease. However, no study has been conducted so far on the anticancer activity of Bangladeshi wild date palm fruits (Phoenix sylvestris) despite the fact that it contains apigenin, quercetin, glucans, luteolin, and iron and vitamin complex. Therefore, in this review we discussed an idea that potential anticancer agents can be isolated from the extract of these fruits, which can eventually be used as an indigenous substance for the treatment of Hepatocellular carcinoma in our country and also the liver cancer inhibitory effects of the aqueous extract of these dates can be evaluated in rat model.
\end{abstract}

\section{Introduction}

Cancer is a multi-factorial disease that is not only a global health issue but also an economic burden worldwide. Although cancer treatment may include chemotherapy, radiation, and/or surgery, but patients can have side effects which usually vary from person to person, even if the type of cancer and treatment is same with other patients having effective results (Huang et al., 2017). Hepatocellular carcinoma (HCC) is the second most common cause of cancer death and there are approximately 800,000 deaths per annum globally due to HCC (Zhu et al., 2016). This disease is one of the leading causes of cancer associated deaths in Bangladesh as well. It is estimated by the International Agency for Research on Cancer (IARC) that cancer-related death rates in Bangladesh to be $13 \%$ within 2030 (Hussain et al., 2013). So, there should be safe, effective and affordable approaches to control the development and progression of this disease. Many natural products, such as fruits and vegetables, are promising 
amends as they are not much expensive and also available without any hazards (Chowdhury et al., 2008).

Date fruits are of barren region immensely cultivated as an economical food crop in the Middle East, Bangladesh, India, Sri-lanka and Pakistan. Date fruit (Phoenix sylvestris) is known as a local sweet fruit in Bangladesh which belongs to the family of Arcaceae. The native name of this wild date palm fruit is "Khejur" in Bengali language (Boeing et al., 2012). Some species of Phoenix are able to produce sap all the year round, but $P$. sylvestris only can seasonally produce the sap which is rich in carbohydrate, protein, potassium, sodium, vitamin B-complex and vitamin C (Salvi et al., 2012). The chemical composition of Phoenix sylvestris sweet juice was reviewed in a study which revealed that these fruits contain vitamin B12, ascorbic acid, nicotinic acid etc. (Jain et al., 2018).

Potential anticancer agents can be isolated from the extract of these fruits that can be used as an indigenous substance to treat HCC in our country, as different studies have suggested that it contains apigenin, quercetin, glucans, luteolin which also exhibit antimicrobial activities against imipenem-resistant $P$. aeruginosa (IRP) (Selim et al., 2012). As wild dates are available at reasonable price in Bangladesh, research and treatment could be done easily with low cost than the expensive chemotherapeutic approaches. Since no study has been conducted so far regarding the anticancer activity of Bangladeshi wild date fruits against $\mathrm{HCC}$, the research could bring significant development in social and economic sectors of Bangladesh.

Both the pulp and flower of wild dates ( $P$. sylvestris) contain essential anticancer components, and thus can be useful against liver cancer. A study on male flower inflorescence of Phoenix sylvestris has revealed that $\beta$ amyrin and quercetin as its phytoconstituents (Hasan et al., 2010). Quercetin is a natural polyphenolic flavonoid that can significantly inhibit cell proliferation by inducing apoptosis which leads to the alteration of cell cycle in HepG2 cells. It also reduced the gene expression of cyclin D1 in HepG2 cells to significantly inhibit the development and proliferation of HepG2 cells (Zhou et al., 2017). Another compound found in male flower inflorescence of Phoenix sylvestris is $\beta$-amyrin, which exhibits significant anticancer activity against liver cancer cells. The $\beta$-amyrin has been found to be able to trigger the apoptosis and cell cycle disruption. This can also mediate activation of p38 and JNK signaling pathways (Wen et al., 2018).

\section{Ajwa Date (Phoenix dactilyfera): Prominent Source of Anticancer Agents}

Ajwa dates (Phoenix dactilyfera) are a delicious and luscious fruit from Saudi Arabia that are cultivated mostly in Madina Tayyiba. There are some studies suggesting that these dates contain many flavonoid glycosides which have anti-oxidant properties. Even Ajwa dates can be beneficial for people who suffer from Type 2 diabetes because it has only monosaccharaides. However, these dates are most expensive and are only found in certain regions of Saudi Arabia (Khalid et al., 2017).

The cyclooxygenase (COX) enzymes; COX-1 and COX-2 are mediators of the inflammatory pathway which have a role in hepatocarcinogenesis (Cervello et al., 2006). It is discovered by a study that COX-2 enzyme is excessively expressed in HCC which also regulate the HCC development and progression (Selim et al., 2012).One different study has revealed that HCC cells become more tumorigenic and can alter basal functional capacities by growth factors-induced epithelial-mesenchymal transition (EMT).COX-2 and the Akt pathway inhibition can halt the process of EMT and inhibition of COX-2 completely reversed the process; and therefore $\mathrm{COX}-2$ inhibitors can be explored as chemo-preventative agents in HCC (Ogunwobi et al., 2012).According to a study, ethyl acetate, methanolic, and water extracts of Ajwa dates can be the inhibitors of COX-1 and COX-2 which can inhibit the development and progression of HCC (Zhang CR et al., 2013).

A study in animal model also showed that $P$. dactylifera pollen has potential protective effect in atypical prostatic hyperplasia (ATP)-induced Wistar rats via modulation of cytokines expressions (Elberry et al., 2011). A recent study on Ajwa dates also found that Ajwa date pulp (ADP) extract can induce cytotoxicity and underlying mechanism of apoptotic cell death on human liver carcinoma HepG2 cells due to the presence of $\beta$-D-glucan as an active component in ethanolic extract of ADP (Siddiqui et al., 2019). Moreover, it has been reported by another study that $\beta$ glucan from Libyan Ajwa dates found to exhibit potent antitumor activity against solid tumor in mice, which was found to be related to $(1 \rightarrow 3)-\beta$-D-glucan linkages (Ishurd et al., 2005).

A previous study has revealed that the methanolic extract of Ajwa dates can inhibit the growth of human breast cancer MCF7 cells and ethyl acetate extract of Ajwa dates has been found to reduce the growth of prostate cancer PC3 cells by causing cell cycle arrest (Khan et al., 2016; Mirza et al., 2018).

Apigenin, quercetin and luteolin, the major flavonoids present in Ajwa date, could be one of the reasons for reduced serum levels of proinflammatory cytokines (IL-1 $\beta$, TNF- $\alpha$ and IL-6) which also showed hepatoprotection in DEN-induced HCC in rats (Chowdhury et al., 2008; Brito et al., 2016).

The aqueous extract of Ajwa dates (ADE) helped in the reversal of diethylnitrosamine (DEN) damaged liver towards normal in a study. ADE has been found to improve liver function and inhibit HCC through the restoration of anti-oxidant enzymes and liver enzymes, cytokines balance, and down regulation of IL-6 gene expression levels (Torisu 
et al., 2000). According to a study, the administration of luteolin $(20 \mu \mathrm{g} / \mathrm{kg}$ bw, intraperitoneally) in mice decreased the plasma levels of Alpha-Feto-Protein (AFP) that was initially ameliorated after DEN treatment. ADE can, therefore, be used together with conventional therapeutics for the treatment of HCC (Khan et al., 2017).

\section{The Most Abundant Elemental Contents of Wild Date Palm (Phoenix sylvestris)}

Wild date palm is widely grown in South Asia, from Pakistan to Myanmar, across India, Nepal, Bhutan, and it plays an important role in the economic development of Bangladesh. These monocotyledonous, dioecious, C4 perennial tall tree plant belongs to Arecaceae family, which grow naturally in Bangladesh. There are several stages in the development; nutritive and chemical changes during the growth of date fruit. (Al-Hooti et al., 1997). The most utilized part of wild date palm in Bangladesh is the sweet sap that contains good nutrient supplement and rich in carbohydrate, protein, minerals, Vitamin A, B-complex and ascorbic acid. Thus, it is a good source of healthy drink to alleviate malnutrition (Swaraz et al., 2017).

Phytochemical screening of crude hexane, dichloromethane and methanol leaf extracts of $P$. sylvestris was performed which exhibited the presence of various biologically active compounds such as aldehydes, alcohols, flavonoids, phenolics (Singh et al., 2016).

Phenolic compounds in the date palm seeds can be used to reduce levels of free radicals through steeping process. A study on date palm seed steeping against free radical products (MDA) and antioxidant vitamins (vitamin E) in the alloxan induced rat model has revealed that date palms seed could successfully decrease the levels of MDA and uplift the vitamin E levels (Saryono et al., 2017). The findings of a study showed that having high relative percentages of oleic acid and conferring protection against UV light to prevent cellular damage make date seed oil a promising candidate for use in cosmetics and food industries (ElMassry et al., 2019).

Paraoxonase 1 (PON1) is a high- density lipoprotein (HDL)-associated antioxidant enzyme which is produced in the liver. PON1 is involved in a variety of inflammatory diseases, metabolizing toxic oxidized lipids and hydrolyzing several organophosphorus (OP) insecticides, nerve agents, some of drugs and endogenous lactones (Androutsopoulos et al., 2011). A study demonstrated that administration of date seed extract (DSE) can significantly increase the serum paraoxonase and arylesterase activity in hyper-cholesterolemic rats and it might be useful in decreasing symptoms of diseases related to the low activity of paraoxonase or can overcome diseases due to the increasing activity of paraoxonase likewise OP (Takaeidi et al., 2014).
Low-density lipoprotein (LDL) cholesterol is the most important contributing factor for heart attacks, stroke and heart diseases. Dose of 20-35gms of dates make heart healthier by significantly reducing LDL level in blood and very useful for geriatric cases in relieving bone ache, improving digestion, raising $\mathrm{Hb}$, minimizing fatigue. Besides acting as a brain tonic making old age people mentally active, it can enhance bowel movement, digestion (Verma, 2016). For having phenolic compounds, dates can act as anti-viral, -bacterial and -fungal agents, which can be used as remedy for certain diseases and can cure chronic inflammations. Being very rich in dietary fibers, selenium, carotenoids, ascobate, and other essential antioxidant, its by-products may prevent the oxidative damages (El Hadrami and Al-Khayri, 2012).

Absence or poor amount of blood factors such as hemoglobin ( $\mathrm{Hgb})$, hematocrit (Hct), and ferritin may exhibit Iron deficiency anemia (IDA) in school students specially. Consumption of raw sap or pulps of date can ameliorate $\mathrm{Hgb}$, Hct, and ferritin levels in patient. Date is full of vitamin $\mathrm{C}$ and dietary fibers which increase absorption of iron in anemic patients (Irandegani et al., 2019). The antioxidant activity of different types of extracts (methanolic, acidic, ethanolic and basic ethanolic) of the wild date fruit showed significant reduction of oxidative stress at the in vivo and in vitro level. Basic ethanolic is the most potent extract to scavenge hydroxyl radical and methanolic extract is the most potent extract to scavenge the NO molecules (Mukherjee et al., 2014; Das et al., 2015).

Radio protective agents are compounds which significantly can reduce the adverse effects of radiation over cell through one or more mechanisms, such as, scavenging of free radical, repairing by hydrogen donation to target molecules, formation of mixed sulfides, delaying of cellular division, raising cytokines production, DNA repairing, and inhibition of protease in cell. According to a study, date seed extract may act as radio protective agent, which was injected into mice before gamma irradiation and protected mice from lethal effects of total body irradiation without any sideeffects (Khezerloo et al., 2019).

\section{Approaches of Isolating Anticancer Agents from $P$. sylvestris}

Hepatocellular carcinoma inhibitory effects of the aqueous extract of wild dates, collected from different regions of Bangladesh, could be evaluated in rat model having diethylnitrosamine (DEN) induced liver cancer through studying the histological, biochemical and antioxidant enzyme status, as well as the related cytokines and gene expression profiles (Khan et al., 2017). Blood and liver tissues from all the HCC affected animals could be isolated in different experimental groups. The result of histological analysis should show the normal hepatocytes in the high concentration of WDE treated group than other groups and 
DEN control group should have abnormal cell morphology (Khan et al., 2017). The anti-oxidant enzymes such as superoxide dismutase (SOD), glutathione reductase (GR), glutathione peroxidase (GPx) and catalase (CAT) could be analyzed. The activity of the anti-oxidant enzymes is supposed to be increased in WDE treated groups compared to untreated control (Khan et al., 2017).

Lipid Hydroperoxide (LPO) assay could be carried out. Following the end point assay, the specific absorbance could be determined spectrophotometrically. Malondialdehyde (MDA) levels are supposed to be increased mildly in DEN control and WDE treated group with less concentration; as well as to be decreased in high concentrated WDE treated group compared to untreated control (Khan et al., 2017).

The activity of the following liver enzymes namely, alanine aminotransferase (ALT), aspartate aminotransferase (AST) and alkaline phosphatase (ALP) could be measured. Following incubation for $5 \mathrm{~min}$, the absorbance for ALT, AST could be determined spectrophotometrically. Liver enzymes: alanine aminotransferase (ALT), aspartate aminotransferase (AST) and alkaline phosphatase (ALP) are supposed to be decreased in all WDE treated groups compared to DEN control (Khan et al., 2017).

Serum samples from WDE treated rats could be analyzed for both pro-inflammatory and anti-inflammatory cytokines using the Rat Cytokine Magnetic 10-Plex Panel. Next, the magnetic beads in solution could be added and washed twice with $1 \mathrm{X}$ wash buffer. Standards and samples could be prepared and added to the washed beads and incubated on an orbital shaker at $500 \mathrm{rpm}$ for $2 \mathrm{hrs}$. The plate could then be incubated with detection antibodies for $1 \mathrm{hr}$ and streptavidin-RPE antibodies for $30 \mathrm{~min}$ incubation. During incubations with various antibodies, the plate could be washed twice with wash buffer. After the antibody incubation is done, the plate could finally be washed thrice and re-suspended in wash buffer and could be analyzed using on MAGPIX® instrument. Data obtained could be analyzed using the Luminex xPONENT multiplex assay analysis software. The cytokines analysis in WDE treated groups should demonstrate a decrease in the proinflammatory cytokines (IL-1 $\beta$, IL- $1 \alpha$, and GM-CSF) and an increase in the anti-tumor cytokines IL-2, IL-10 and IL-12. However, the concentrations of most of the proinflammatory cytokines should only be increased in DEN control group (Khan et al., 2017).

\section{Conclusion}

The main goal of this review paper is to give the overview of the importance of the potential anticancer activities of wild dates from Bangladesh. Date fruits are rich in nutrients, vitamins and phenolic compounds which make it a crucial natural food. Having date fruit can protect people from various bacterial and multifactorial disorders, which are demonstrated by different studies. Apart from the date pulp; date leaves, seeds, sap are also important for different health benefits. Therefore, more scientific research should be done on all the parts of date tree and fruits, specially to evaluate whether wild date from Bangladesh could act as anticancer agent against Hepatocellular carcinoma like Ajwa date, which could be beneficial for the social and economic conditions of Bangladesh as well.

\section{Authors' Contribution}

Both of authors jointly designed the research plan; Farhana Shikder Lamia performed experimental works, collected the required data \& prepared the manuscript. Roushney Fatima Mukti analysed the data, critically revised and finalized the manuscript. Final form of manuscript was approved by both of authors.

\section{Conflict of Interest}

The authors declare that there is no conflict of interest with present publication.

\section{References}

Al-Hooti S, Sidhu J S, Qabazard H (1997) Physicochemical characteristics of five date fruit cultivars grown in the United Arab Emirates. Plant Foods Hum Nutr50(2): 101113. DOI: $\underline{10.1007 / \mathrm{bf} 02436030}$.

Androutsopoulos VP, Kanavouras K, and Tsatsakis AM (2011) Role of paraoxonase 1 (PON1) in organophosphate metabolism: implications in neurodegenerative diseases.Toxicol Appl Pharmacol 256(3): 418-24 DOI: 10.1016/j.taap.2011.08.009.

Boeing H, Bechthold A, Bub A., Ellinger S, Haller D, Kroke A, and Watzl B (2012) Critical review: vegetables and fruit in the prevention of chronic diseases. Eur J Nutr.51(6): 637-663. DOI: $10.1007 / \mathrm{s} 00394-012-0380-\mathrm{y}$.

Brito AF, Ribeiro M, Abrantes AM, Mamede AC, Laranjo M, Casalta-Lopes JE, Gonçalves AC, Sarmento-Ribeiro AB, Tralhão JG, and Botelho MF (2016) New approach for treatment of primary liver tumors: the role of Quercetin. NutrCance r68: 250-266. DOI: $\underline{10.1080 / 01635581.2016 .1145245}$.

Cervello M, Montalto G (2006) Cyclooxygenases in hepatocellular carcinoma. World $J$ Gastroenterol 12(32): 5113-5121 DOI: $10.3748 /$ wjg. 12.5113 .

Chowdhury MSH, Halim MA, Md Abdul, and Muhammed N et al. (2008) Traditional utilization of wild date palm (Phoenix sylvestris) in rural Bangladesh: An approach to sustainable biodiversity management. J For Res (Harbin) 19: 245-251. DOI: 10.1007/s11676-008-0036$\underline{1}$.

Das R, Paul P., Mukherjee K, Mitra S, Singh U, and Banerjee E (2015) Anti-Oxiflammatory Profile of Date Extracts (Phoenix sylvestris). Biomed Res Ther2(6): 297-317 DOI: $10.15419 /$ bmrat.v2i06.53.

El Hadrami A, Al-Khayri MJ (2012) Socioeconomic and traditional importance of date palm. Emir $J$ Food Agric24: 371-385 DOI: 10.9755/ejfa.v25i4.15492.

Elberry AA, Mufti S T, Al-Maghrabi J A, Abdel-Sattar E A, Ashour O M, Ghareib S A, and Mosli H A (2011) Antiinflammatory and antiproliferative activities of date 
palm pollen (Phoenix dactylifera) on experimentallyinduced atypical prostatic hyperplasia in rats. $J$ Inflamm (Lond). 8(1): 40. DOI: 10.1186/1476-9255-8-40.

El-Massry K, El-Ghorab A, Farouk A, Hamed S, Elgebaly H, Mosa N, Alsohaimi I, Mahmoud A (2019) Microencapsulation of Date Seed Oil by Spray-drying for Stabilization of Olive Oil as a Functional Food. Asian $J$ Sci Res 12(4): 516-523. DOI: 10.3923/ajsr.2019.516.523.

Hasan MM, Ahmed S W, Azhar I, and Bano H (2010) Phytoconstituents isolated from Phoenix sylvestrisRoxb. J Basic Apply Sci 1: 17-22.

Huang C Y, Ju D T, Chang C F, Muralidhar R P, and Velmurugan B K (2017) A review on the effects of current chemotherapy drugs and natural agents in treating nonsmall cell lung cancer. Biomedicine (Taipei) 7(4): 23. DOI: $10.1051 / \mathrm{bmdcn} / 2017070423$.

Hussain S A, and Sullivan R(2013) Cancer control in Bangladesh. Jpn J Clin Oncol 43(12): 1159-1169. DOI: 10.1093/jjco/hyt140.

Irandegani F, Arbabisarjou A, Ghaljaei F, Navidian A, and Karajibani M (2019) The Effect of a Date ConsumptionBased Nutritional Program on Iron Deficiency Anemia in Primary School Girls Aged 8 to 10 Years Old in Zahedan (Iran). Pediatric Health Med Ther 10: 183-188 DOI: 10.2147/PHMT.S225816.

Ishurd O, and Kennedy J F (2005) The anti-cancer activity of polysaccharide prepared from Libyan dates (Phoenix dactylifera L.). CarbohydrPolym59(4): 531-535. DOI: 10.1016/j.carbpol.2004.11.004.

Jain P, Jain S, Sharma S, and Sarvesh P (2018). Diverse application of Phoenix sylvestris: A potential herb. Agriculture and Natural Resources 52(2). DOI: 10.1016/j.anres.2018.06.006.

Khan F, Ahmed F, Pushparaj P N, Abuzenadah A, Kumosani T, Barbour E, Al Qahtani M, and Gauthaman K (2016) Ajwa Date (Phoenix dactylifera L.) Extract Inhibits Human Breast Adenocarcinoma (MCF7) Cells In Vitro by Inducing Apoptosis and Cell Cycle Arrest. PloS one 11(7): e0158963 DOI: $\underline{10.1371 / \text { journal.pone.0158963. }}$.

Khan F, Khan TJ, Kalamegam G, Pushparaj PN, Chaudhary A, Abuzenadah A, Kumosani T, Barbour E, and Al-Qahtani M (2017) Anti-cancer effects of Ajwa dates (Phoenix dactylifera L.) in diethylnitrosamine induced hepatocellular carcinoma in Wistar rats. $B M C$ Complement Altern Med 17(1): 418. DOI: https://bmccomplementmedtherapies.biomedcentral.co m/articles/10.1186/s12906-017-1926-6.

Khezerloo D, Mortezazadeh T, Farhood B, Zadeh PS, Seyfizadeh N, Pezhman L (2019) The effect of date palm seed extract as a new potential radioprotector in gamma-irradiated mice. J Can Res Ther3(15): 517-521 DOI: $\underline{10.4103 / j \text { jert.jcrt } 1341 \quad 16 .}$.

Swaraz AM, Satter MA, Sumi SK (2017) Assessment of yield and nutritional composition of fruit of wild date palm (Phoenix sylvestris Roxb.) cultivars. Int. J. Biosci11(4): 85-91. DOI: /10.12692/ijb/11.4.85-91.

Mirza M B, Elkady A I, Al-Attar A M, Syed F Q, Mohammed F A, and Hakeem K R (2018) Induction of apoptosis and cell cycle arrest by ethyl acetate fraction of Phoenix dactylifera (Ajwa dates) in prostate cancer cells. $J$
Ethnopharmacol218:

$35-44$

DOI:

10.1016/j.jep.2018.02.030.

Mukherjee K, Pramathadhip P, and Banerjee ER (2014) Free Radical Scavenging Activities of Date Palm (Phoenix sylvestris) Fruit Extracts. Nat Prod Chem Res 2(6) DOI: 10.4172/2329-6836.1000151.

Ogunwobi OO, Wang T, Zhang L, and Liu C (2012) Cyclooxygenase- 2 and Akt mediate multiple growthfactor-induced epithelial-mesenchymal transition in human hepatocellular carcinoma. J Gastroenterol Hepatol 27(3): $\quad 566-578 . \quad$ DOI: $\underline{10.1111 / j .1440-}$ 1746.2011.06980.x.

Verma P (2016) Effect of Dates in Lowering LDL Level in Geriatric Cases. Health Sci J $\mathbf{1 0 .}$

Khalid S, Khalid N, Sanaullah RK, Haroon A, Asif A (2017) A review on chemistry and pharmacology of Ajwa date fruit and pit. Trends Food Sci Technol63: 60-69. DOI: 10.1016/j.tifs.2017.02.009.

Dr Salvi J, Katewa SS. (2012) Chemical composition and nutritive value of sap of Phoenix sylvestrisRoxb. EJEAFChe11: 578-583.

Saryono, Rahmawati E, Hidayat AI, Hisni D and Proverawati A (2017) Plasma Malondialdehyde and Vitamin E Levels after Date Palm Seeds (Phoenix dactylifera) Steeping Administration. Asian J. Clin. Nutr. 9: 131-136. DOI: 10.3923/ajen.2017.131.136.

Selim S, Alfy SE, Al-Ruwaili M, Abdo A, and Jaouni S A (2012) Susceptibility of imipenem-resistant Pseudomonas aeruginosa to flavonoid glycosides of date palm (Phoenix dactylifera L.) tamar growing in Al Madinah, Saudi Arabia. Afr. J. Biotechnol. 11(2): 416-422.DOI: 10.5897/ajb11.1412.

Shiota G, Okubo M, Noumi T, Noguchi N, Oyama K, Takano Y, Yashima K, Kishimoto Y, Kawasaki H (1999) Cyclooxygenase-2 expression in hepatocellular carcinoma. Hepatogastroenterology46(25): 407-412.

Siddiqui S, Ahmad R, Khan M A, Upadhyay S, Husain I, \& Srivastava A N (2019) Cytostatic and Anti-tumor Potential of Ajwa Date Pulp against Human Hepatocellular Carcinoma HepG2 Cells. Sci Rep 9(1): 245. DOI: 10.1038/s41598-018-36475-0.

Singh S, Sharma B, Kanwar SS, \& Kumar A (2016) Lead Phytochemicals for Anticancer Drug Development. Front Plant Sci 7: 1667. DOI: 10.3389/fpls.2016.01667.

Takaeidi M R, Jahangiri A, Khodayar M J, Siahpoosh A, Yaghooti H, Rezaei S, Salecheh M, \& Mansourzadeh Z (2014) The Effect of Date Seed (Phoenix dactylifera) Extract on Paraoxonase and Arylesterase Activities in Hypercholesterolemic Rats. undishapur J Nat Pharm Prod 9(1): 30-34. DOI: 10.17795/ijnpp-10368.

Torisu H, Ono M, Kiryu H, Furue M, Ohmoto Y, Nakayama J, Nishioka Y, Sone S, \& Kuwano M (2000) Macrophage infiltration correlates with tumor stage and angiogenesis in human malignant melanoma: possible involvement of TNFalpha and IL-1alpha. Int J Cancer 85(2): 182-188. 


\section{DOI: $\quad \underline{10.1002 /(S I C I) 1097-}$ \\ 0215(20000115)85:2<182::AID-IJC6>3.0.CO;2-M}

Wen S, Gu D, Zeng H (2018) Antitumor effects of beta-amyrin in Hep-G2 liver carcinoma cells are mediated via apoptosis induction, cell cycle disruption and activation of JNK and P38 signalling pathways. J Buon 23(4): 965-970.

Zhang CR, Aldosari SA, Vidyasagar PS, Nair KM and Nair MG (2013) Antioxidant and anti-inflammatory assays confirm bioactive compounds in Ajwa Date fruit. J Agric Food Chem61(24): 5834-5840 DOI: 10.1021/jf401371v.

Zhou J, Fang L, Liao J, Li L, Yao W, Xiong Z \& Zhou X (2017) Investigation of the anti-cancer effect of quercetin on HepG2 cells in vivo. PloS one 12(3): e0172838 DOI: /10.1371/journal.pone.0172838

Zhu RX, Seto WK, Lai CL \& Yuen MF (2016) Epidemiology of hepatocellular carcinoma in the Asia-Pacific region. Gut Liver 10(3): 332. DOI: 10.5009/gnl15257. 